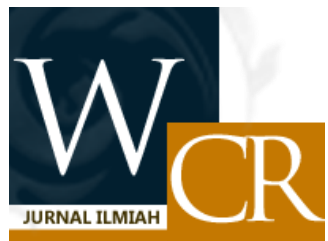

\title{
Peranan Material Interior dalam Pengendalian Akustik Auditorium Bandung Creative Hub
}

\author{
${ }^{1}$ Alnugraha Rachman Putra $\mid{ }^{1}$ Ryanty Derwentyana Nazhar \\ ${ }^{1}$ Program Studi Desain Interior, Fakultas Desain, Universitas Komputer Indonesia, Bandung, Jawa Barat, Indonesia \\ *Corresponding author : email : alnugraha@ rocketmail.com
}

\begin{abstract}
ABSTRAK
Akustika dalam sebuah interior auditorium memiliki peranan yang vital terhadap keberlangsungan kegiatan di dalamnya. Kegiatan di dalam auditorium erat kaitannya dengan audio dan visual, maka perancangan sebuah auditorium membutuhkan suatu sistem pengendalian akustik, bukan hanya unsur visual saja yang diperhatikan, tetapi juga dalam hal pengendalian suara atau akustik membutuhkan perhatian khusus. Penelitian ini memaparkan peran material interior dalam pengendalian akustika pada auditorium multifungsi di gedung Bandung Creative Hub, Jawa Barat. Untuk mengetahui kualitas akustik ruangan yang diteliti, maka metode penelitian yang digunakan adalah analisis deskriptif dengan mengolah data berupa gambar, pencatatatan lapangan, dokumentasi, dan juga teori-teori pendukung disesuaikan dengan kaidah ilmu desain interior. Penelitian ini menyimpulkan bahwa material interior pada auditorium multifungsi di Gedung Bandung Creative Hub sudah memenuhi standar yang berlaku dalam pengendalian akustika ruang auditorium. Manfaat dari penelitian ini adalah dapat menjadi tolak ukur suatu perancangan auditorium dan dapat menjadi referensi untuk perancangan ruang yang memerlukan perlakuan akustik khusus di masa mendatang.
\end{abstract}

Kata kunci: Akustik, auditorium, standar akustik, material akustik

\begin{abstract}
Acoustics in an auditorium interior has a vital role in the continuity of activities in it. Activities in the auditorium are closely related to audio and visual, so designing an auditorium requires an acoustic control system, not only visual elements are considered, but also sound or acoustic control requires special attention. This study describes the role of interior materials in acoustic control in a multifunctional auditorium in the Bandung Creative Hub building, West Java. To determine the quality of the room acoustics under study, the research method used is the descriptive analysis by processing data in the form of images, field notes, documentation, and supporting theories according to the principles of interior design science. This study concludes that the interior materials in the multifunctional auditorium in the Bandung Creative Hub Building have met the applicable standards in the acoustic control of the auditorium space. The benefit of this research is that it can be used as a benchmark for auditorium design and can be a reference for space design that requires special acoustic treatment in the future.
\end{abstract}

Keywords: Acoustics, auditorium, acoustic standard, acoustic materials

\section{PENDAHULUAN}

Gedung Bandung Creative Hub (BCH) memiliki banyak ruangan dan fasilitas, salah satu fasilitas yang sering digunakan untuk berbagai kebutuhan adalah Auditorium multifungsi. Auditorium multifungsi merupakan salah satu ruangan yang "spesial" dikarenakan dalam perancangannya membutuhkan rancangan yang berebeda dengan ruangan yang lainnya, pada rancangan interior ruang auditorium tidak hanya fungsi estetika yang diutamakan, tetapi fungsi akustika pun menjadi hal 
yang patut diperhatikan. Akustika memegang peranan utama dalam sebuah auditorium dikarenakan fungsi auditorium yang erat kaitannya dengan audio dan visual. Dalam interior auditorium terdapat beberapa hal yang berpengaruh terhadap kondisi akustik dan kualitas akustik yang ada, salah satu yang penting adalah pemilihan dan penggunaan material.

Didalam dunia desain interior, terdapat sangat banyak sekali opsi dalam hal material yang dapat dipadukan satu dengan yang lainnya, unsur materialpun dapat dipadukan dengan unsur yang lain semisal warna dan atau bentuk. Pemilihan material dapat disesuaikan dengan fungsi dan kebutuhan yang diperlukan, dalam kasus pengendalian akustik material yang dibutuhkan adalah material yang memiliki kemampuan akustik, semisal pemilihan material yang memiliki kemampuan meredam bunyi atau material yang dapat memantulkan bunyi. Unsur material dalam pengendalian akustik memegang peranan yang penting, dikarenakan pemilihan material yang salah dapat mengacaukan kondisi akustik yang ada, material merupakan salah satu unsur yang dapat mencakup dua hal yaitu keindahan secara visual dan fungsi terhadap akustika. Selain itu unsur material merupakan salah satu unsur yang bersinggungan langsung dengan gelombang bunyi, seperti penggunaan material karpet pada lantai, selain sebagai estetika, material karpet juga menjadi hal yang paling pertama menerima gelombang bunyi dan dapat dirasakan langsung perananya sebagai pengendali kondisi akustik.

Pada penelitian ini, akan membahas mengenai peranan material sebagai salah satu unsur dalam usaha pengendalian akustik auditorium multifungsi Bandung Creative Hub, menganalisa penggunaan material pada interiornya yang kemudian akan disesuaikan dengan teori dalam ilmu desain interior dan juga teori akustika, agar mendapat gambaran mengenai kondisi akustik yang ada pada interior auditorium multifungsi Bandung Creative Hub apakah perancangannya sesuai dengan teori yang ada atau tidak, hal ini dapat berdampak pada keberlangsungan aktivitas yang dilakukan di dalam auditorium.

\section{METODE}

Penelitian ini menggunakan metode penelitian analisa deskriptif, yaitu data berupa dokumentasi area studi kasus dan pencatatan kondisi aktual di lapangan dianalisa dan diuji kesesuaiannya dengan teori interior dan akustika secara umum agar mendapat gambaran kualitas dari objek yang diteliti.

Penelitian ini menggunakan studi kasus Auditorium Bandung Creative Hub. Auditorium ini merupakan auditorium dengan jenis multifungsi, yaitu fasilitas yang digunakan untuk berbagai jenis acara, sehingga pertanyaan permasalahannya adalah Bagaimana pengendalian akustika Auditorium Bandung Creative Hub ditinjau dari perancangan elemen interiornya interiornya. Elemen interior yang dibahas dalam artikel ini adalah perlakuan desain pada lantai, dinding, ceiling, dan furniturnya.

\section{PEMBAHASAN}

C. E. Mediastika (2005) menyatakan bahwa auditorium merupakan sebuah ruangan yg diperuntukkan untuk mengadakan pertemuanpertemuan umum, aktivitas pertunjukan, dan lain sebagainya, sedangkan auditorium multifungsi merupakan jenis auditorium yang tidak dirancang secara khusus untuk fungsi verbal atau musik, namun dirancang untuk berbagai aktivitas lain, seperti mengadakan pernikahan, pameran produk, dan aktivitas perayaan seperti ulang tahun dan lain sebagainya.

Akustika diartikan sebagai sesuatu yang berkaitan dengan suara atau bunyi. Menurut Shadily, (1987:8) akustik berarti ilmu suara atau ilmu bunyi. Sedangkan Halme (1990, h.12) menyatakan bahwa akustik adalah salah satu bentuk ilmu dan merupakan pertimbangan pertama untuk mendapatkan lingkungan ataupun ruang dengan suara yang nyaman.

Sedangkan desain interior menurut Cohen (1994), merupakan aktivitas merancang, menata, merencanakan suatu ruang dalam bangunan. Penataan pada suatu ruang memiliki tujuan agar pengguna ruang tersebut merasa aman, nyaman, senang, dan betah berada di ruangan tersebut.

Pengendalian bising dan akustik pada ruang arsitektur dapat dilakukan dengan mengendalikan getaran dan juga penggunaan material bangunan yang efektif (Long, 2006). Salah satu upaya yang dapat dilakukan untuk mengatasi kebisingan dan bunti yang tidak diinginkan adalah dengan pemasangan bahan penyerap suara, yaitu dengan pemilihan material yang dapat mengurangi 
mereduksi kebisingan dan kekuatan suara hingga $10 \mathrm{~dB}$ (Rossing et al, 2007). Sedangkan menurut Cox dan D'Antonio (2009), dengan penambahan bahan yang memiliki kemampuan penyerapan suara, kebisingan menurun sampai 3-4 dBA, dan tingkat gema dalam ruang akan berkurang.

Material akustik yang memiliki kemampuan sebagai peredam suara, biasanya ditandai dengan adanya pori. Kemampuan menyerap suara dari material ini tergantung pada variabel ketebalan, kerapatan, dan arah seratnya. Material penyerap suara yang memiliki pori-pori dengan memanfaatkan limbah serat alam menjadi bentuk papan komposit (Kang, 2007). Sedangkan menurut Satwiko (2009), pemilihan bentuk, arah atau orientasi ruang, dan pemilihan material permukaan ruang akan menentukan kualitas dan kuantitas bunyi, yang kemudian akan menentukan karakter bunyi. Cox dan D'Antonio (2009) memaparkan bahwa penggunaan bahan yang menyerap suara dapat mengatasi masalah akustik, pengurangan kebisingan, dan pengontrol waktu dengung (reverberation time).

1) Material pada Auditorium BCH Pembahasan mengenai material pada interior auditorium multifungsi $\mathrm{BCH}$ akan dilakukan dari bawah ke atas ruangan, atau akan dibahas mulai dari lantai dinding - kemudian langit-langit. Dalam perancangan interior ruangan serupa auditorium seperti; studio musik, studio rekaman, aula sekolah, dan lain sebagainya, penggunaan material akustika wajib diterapkan agar dapat memenuhi standar secara akustik dan kegiatan yang dilaksanakan di dalamnya berjalan sebagaimana mestinya. Pada interior auditorium peran material adalah sebagai salah satu media utama untuk mengendalikan akustika, pada umumnya didalam auditorium digunakan material berpori yang memiliki fungsi sebagai penyerap suara, material berpori terdiri dari berbagai macam contohnya; kain, busa, kapas sintetis, dan lain sebagainya.

\section{a) Lantai}

Dalam interior auditorium multifungsi $\mathrm{BCH}$, pada elemen lantai untuk konstruksi utamanya menggunakan beton bertulang, dengnan finishing keramik yang kemudian ditutupi degan karpet bercorak, pemilihan karpet bercorak memiliki fungsi estetis dan juga fungsi akustik, pada fungsi estetis karpet bercorak lebih menarik ketimbang karpet polos, selain itu corak pada karpet dapatv menyamarkan kotoran sehingga karpet lebih tidak mudah terlihat kotor. Pada sisi akustik material karpet yang memiliki permukaan halus dan banyak pori-pori dari rajutan benangnya, dapat meredam gelombang suara berfrekuensi mid-low atau frekuensi menengah hingga rendah, seperti suara vokal manusia atau suara bass, material karpet dapat menjadi material peredam suara yang cukup efektif.

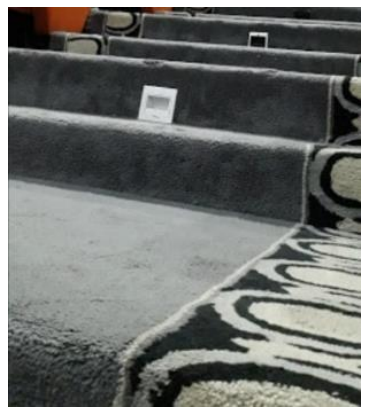

Gambar 1. Material karpet pada tangga auditorium $\mathrm{BCH}$.

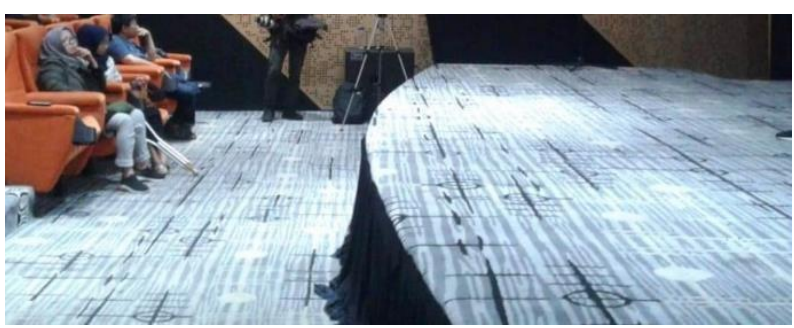

Gambar 2. Material karpet pada lantai dan panggung auditorium $\mathrm{BCH}$

Doelle (1990) menyatakan bahwa material penyerap bunyi yang baik adalah material yang mampu mengubah energi bunyi yang datang menjadi energi panas dalam pori-pori, material tersebut berupa jaringan selular dengan pori-pori yang saling berhubungan. Contoh : mineral wol, plesteran lembut, papan serat, dan selimut isolasi. Selain itu menurut Doelle (1990) penggunaan karpet pada ruang mampu mereduksi dan meniadakan kebisingan akibat benturan seperti bunyi langkah dan seret kaki, dan bunyi benturan akibat aktivitas lainnya. Selain digunakan sebagai bahan penutup lantai, karpet juga dapat difungsikan sebagai bahan penutup pelapis dinding yang akan membuat peredaman suara lebih optimal. 


\section{b) Dinding}

Dinding auditoium BCH memiliki konstruksi utama dari material batu bata yang kemudian digunakan finishing cat tembok. Pada permukaan dindingnya dilapisi oleh treatment berbentuk geometris yang terbuat dari material papan serat (medium density fibre board) yang memiliki permukaan berlubang. Selain material papan serat pada bagian dinding juga memiliki treatment yang dilapisi oleh kain hitam, pada bagian dinding material masih didominasi oleh material berserat atau yang memiliki rongga. Doelle (1990) mnyatakan bahwa bahan yang memiliki rongga merupakan jenis material penyerap bunyi yang efisien dan mampu mengubah energi bunyi yang datang menjadi energi panas.

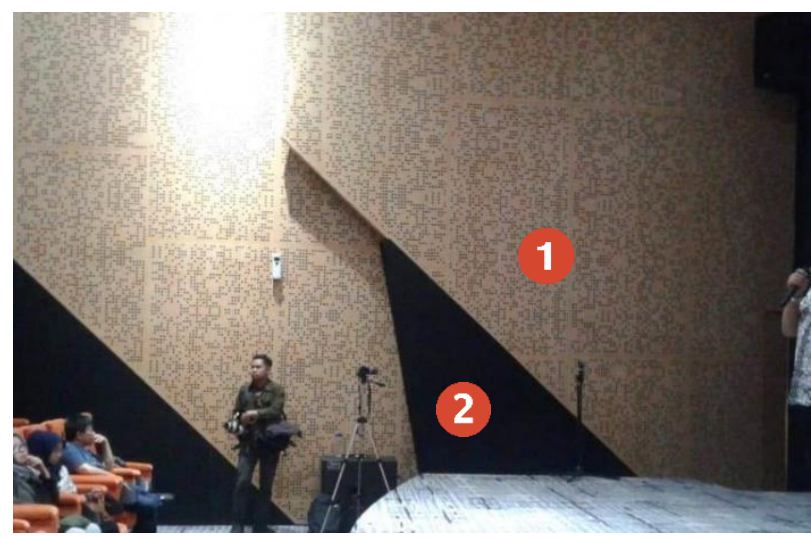

Gambar 3. Treatment dinding auditorium $\mathrm{BCH}$, dengan material papan serat (1), dan kain hitam (2).

Dapat dilihat pada gambar 3, pada bagian treatment dinding digunakan material dengan permukaan berongga pada dinding untuk fungsi akustik menyerap dan memantulkan kembali gelombang bunyi. Menurut Doelle (1990) material panel penyerap (absorber panel) dapat menyerap frekuensi rendah dengan efisien, dan digunakan pada lapisan penunjang yang dipisahkan oleh rongga terletak pada bagian bawah dinding. Bahan ini memiliki ciri bergetar jika menabrak gelombang bunyi, contohnya adalah gypsum board, panel kayu, hardboard, material panel kayu yang dipasang di langit-langit, dan lain sebagainya.

Pada dinding auditorium $\mathrm{BCH}$, penggunaan material papan serat dengan permukaan berongga memungkinkan untuk menyerap dan memantulkan kembali gelombang bunyi, selain karena materialnya, penerapan bentuk geometris dengan penyusunan overlapping pun dapat berfungsi sebagai pemecah gelombang bunyi agar dapat merata ke seluruh ruangan.

\section{c) Furnitur}

Bagian furnishing atau furnitur yang terdapat di dalam interior auditorium $\mathrm{BCH}$ adalah kursi penonton dengan jumlah 156 tempat duduk, pemasangan kursi penonton terletak diatas lantai yang berbentuk miring seperti lereng dengan kemiringan $17^{\circ}$, kemiringan lantai inidimaksudkan agar penonton di kursi belakang tetap bisa mendapat visibilitas yang baik, dan juga dalam sisi akustiknya gelombang bunyi lebih mudah diserap apabila melalui bidang yang miring.

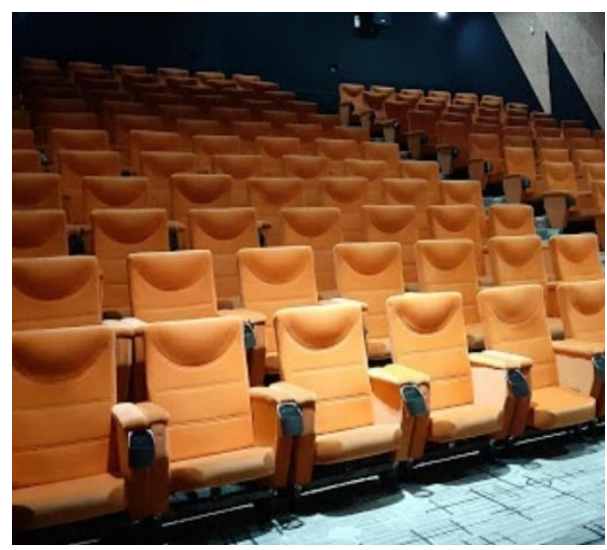

Gambar 4. Tempat duduk penonton dalam auditorium BCH. Sumber:

https://id.pinterest.com/pin/554787247840707604/ (2020)

Seperti yang terlihat pada gambar 4, material furnitur kursi penonton meggunakan busa atau spons yang dilapis dengan upholstery berbahan tekstil, karakteristik bahan busa dan berpori seperti yang telah disebutkan dalam Doelle (1990). Bagian tempat duduk penonton dapat menjadi media pemecah gelombang suara apabila dalam jumlah yang banyak dikarenakan penyusunan tempat duduk yang teratur dan berada pada bidang yang miring, sedangkan material busa pada tempat duduk penonton selain memberikan kenyamanan terhadap audience juga dapat berfungsi sebagai penyerap gelombang bunyi.

\section{d) Langit-langit}


Pada bagian langit-langitnya, auditorium $\mathrm{BCH}$ menggunakan aplikasi material yang hampir serupa dindingnya, yaitu memiliki bentuk geometris dengan penyusunan bertumpuk, penerapan treatment ini memiliki fungsi akustik sama dengan treatment pada dinding, dan juga menggunakan material yang sama dengan treatment dinding yaitu material papan serat, namun pada bagian langitlangit papan serat yang digunakan memiliki permukaan solid dan tidak berlubang seperti pada dinding, hal ini dikarenakan area langit-langit digunakan sebagai media pemantul suara.

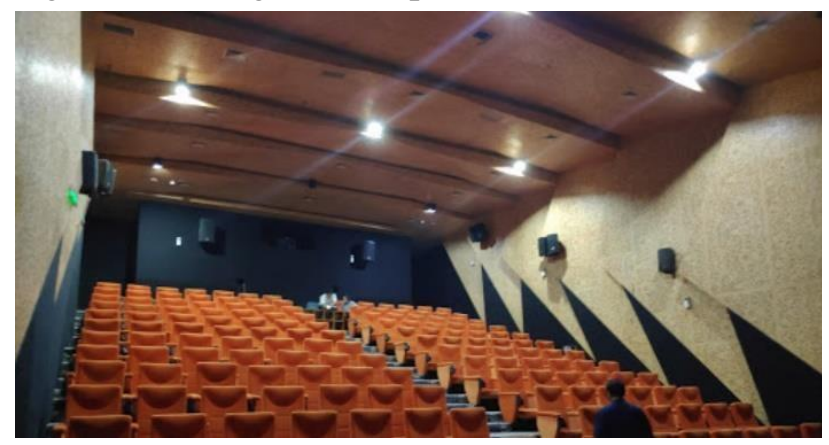

Gambar 5. Langit-langit pada auditorium BCH

Berdasarkan teori akustika menurut Leslie L. Doelle, langit-langit dapat menjadi media pengendalian akustik yang efektif, dengan menempatkan bentuk geometris yang bervariasi guna memantulkan dan memecah gelombang bunyi agar lebih merata dan meminimalisir adanya echo yang tidak diinginkan. Penggunaan material penyerap bunyi yang dipasang pada langit-langit dan dinding ruangan. Penggunaan bentuk geometris dan dimensi yang bervariasi sangat dianjurkan agar dapat memecah dan memantulkan bunyi secara merata.

Material lain yang digunakan pada langit-langit adalah gypsum dan panel kayu. Selain untuk menunjang fungsi akustiknya, pemasangan bentuk geometris pada bagian langit-langit juga dapat berguna untuk memantulkan gelombang bunyi, pemantulan ini diperlukan agar gelombang bunyi yang berasal dari panggung pertunjukkan dapat sampai hingga ke tempat duduk penonton yang paling belakang sekalipun, selain itu pemasangan treatment pada langit-langit dapat memiliki fungsi akustik sebagai pemecah bunyi agar tidak terjadi gaung yang tidak diinginkan.

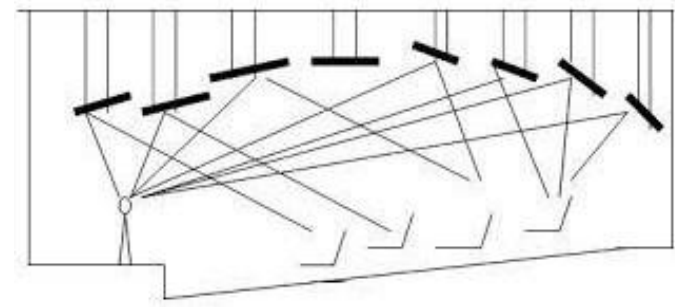

Gambar 6. Pemantul pada bagian langit-langit. Sumber: Leitermann (2017)

Pada auditorium $\mathrm{BCH}$, pemanfaatan permukaan langit-langit sebagai pemantul bunyi, berfungsi sebagai bagian dari pengendalian akustika, yaitu agar bunyi dapat menyebar secara merata di dalam ruangan, dan juga untuk menghindari adanya area bayang-bayang akustika yang diakibatkan oleh jarak dan juga penyusunan ruang. Kombinasi antara bahan penyerap dan bahan pemantul pada ruang auditorium merupakan salah satu cara untuk mengatur kekuatan suara, mengendalikan gaung, dan gema, juga untuk penyebaran suara agar merata.

Ruang auditorium sebagai ruang akustika yang optimal pengendalian akustikanya ditandai oleh pemerataan suara di seluruh area ruangan, artinya baik audiens yang berada di depan, di samping, dan di belakang mendapatkan kualitas suara yang sama baiknya.

\section{KESIMPULAN}

Sebagian besar material yang digunakan pada interior auditorium $\mathrm{BCH}$, dimulai dari elemen lantai, dinding, furnitur, hingga langit- langit sudah sesuai dengan teori dalam ilmu desain interior dan juga akustika yang sudah berlaku. Penggunaan material yang sesuai dengan teori akustika diharapkan dapat menciptakan suatu pengendalian akustik yang baik dan mendukung kualitas kegiatan yang ada di dalamnya. Penggunaan material yang sesuai kemudian dipadukan dengan desain, bentuk, dan penyusunan yang sedemikian rupa diharapkan dapat memaksimalkan kualitas akustik yang ada. Penggunaan material yang tepat pada perancangan sebuah auditorium dapat berfungsi sebagai estetika dan akustika sekaligus. 


\section{DAFTAR PUSTAKA}

D’Antonio, Peter. Cox, Trevor J. 2009. Acoustic Absorbers and Diffusers: Theory, Design and Application. New york. Taylor \& Francis Group. Departemen Pendidikan Nasional. 2008. Kamus Besar Bahasa Indonesia, Pusat Bahasa Edisi Keempat. Jakarta. PT. Gramedia Pustaka Utama.

Doelle, L.L. 1990. Environtmental Acoustic. New york. McGraw-Hill Publishing Company.

Halme, Arthur.1990. Space. Finlandia: Finnish Interior.
Kang, J. 2007. Urban Sound Environment. London. Taylor and Francis.

Long, M. 2006. Architectural Acoustics. Oxford UK. Elsevier.

Mediastika, C. E. 2005. Akustika Bangunan: Prinsipprinsip dan penerapannya di Indonesia. Jakarta. Penerbit Erlangga.

Satwiko, Prasasto. 2009. Fisika Bangunan. Yogyakarta. Andi. 